\title{
Fascin is secreted in male's serum: results of a pilot study
}

\author{
Daniel Porav-Hodade ${ }^{1}$, Orsolya Martha ${ }^{1}$, Daniel Balan*,2, Sabin Tataru1, Adina Hutanu ${ }^{3}$, \\ Anca $\operatorname{Sin}^{2} \&$ Mihai Dorin Vartolomei ${ }^{2,4}$ \\ ${ }^{1}$ University of Medicine \& Pharmacy Tirgu Mures, Department of Urology, Tirgu Mures, Romania \\ ${ }^{2}$ University of Medicine \& Pharmacy Tirgu Mures, Department of Cell \& Molecular Biology, Tirgu Mures, Romania \\ ${ }^{3}$ University of Medicine \& Pharmacy Tirgu Mures, Department of Laboratory Medicine, Tirgu Mures, Romania \\ ${ }^{4}$ Medical University Vienna, Department of Urology, Vienna, Austria \\ * Author for correspondence: Tel.: +40 743186 942; balan_dani@yahoo.com
}

Aim: Fascin is a $55 \mathrm{kDa}$ globular protein with an important role in cell migration. Aim of study was to investigate serum fascin in healthy males. Materials \& methods: From 1 July 2016 to 31 December 2016, we collected serum from 46 males. Serum fascin level was performed using ELISA kit from USBiological (Salem, MA, USA). Results: Median age was 64 years. Mean fascin serum level was $9.84 \mathrm{ng} / \mathrm{ml}, \mathrm{mean}$ prostate-specific antigen (PSA) was $2.74 \mathrm{ng} / \mathrm{ml}$ and mean prostate volume was $37.64 \mathrm{cc}$. The 51-60 years group had a mean of $10.53 \mathrm{ng} / \mathrm{ml}$, the $61-70$ group a mean of $9.7 \mathrm{ng} / \mathrm{ml}$ and the $71-80 \mathrm{group}$ had a mean of $9.41 \mathrm{ng} / \mathrm{ml}$ fascin serum level. Conclusion: Fascin serum level did not differ according to age in males.

Lay abstract: Fascin protein was previously associated with high-grade malignancies. This study presents the determination of fascin serum levels in $\mathbf{4 6}$ healthy males, providing a reference number in further determinations. The patients were divided into three subgroups according to age. The study presents the mean levels of each group, in association with PSA level and the mean prostate volumes. In conclusion, the study states that fascin is secreted in healthy male controls and the levels did not differ according to age.

First draft submitted: 10 August 2017; Accepted for publication: 6 November 2017; Published online: 5 January 2018

Keywords: biomarker $\bullet$ fascin $\bullet$ serum

Fascin is a $55 \mathrm{kDa}$ globular protein with an important role in cell migration. It is a member of a specific family of actin-bundling proteins [1]. The expression of fascin is greatly increased in many transformed cells, as well as in specialized normal cells including neuronal cells and antigen-presenting dendritic cells. The serum level of Fascin-1 is low or almost absent in the normal epithelia, but high levels of Fascin-1 were identified in various cancer types, with an important role in tumor progression, invasion and metastasis [2,3].

Overexpression of fascin immune-expression and its correlation with progressive high-grade tumors, great metastatic potential and poor prognosis had been found in several types of human neoplasms [4-8].

The aim of our study was to see if fascin is secreted in serum and to compare serum levels according to age in healthy male patients.

\section{Materials \& methods}

From 1 July 2016 to 31 December 2016, we collected serum from 46 males that were included in the prostate cancer screening cohort at the Urology clinic. Ethical approval was obtained from the Ethical Committee of the University of Medicine and Pharmacy, Tîrgu Mures, Romania (no. 52 from 24 March 2016). Each subject included in the study signed an informed consent and agreed to enter the study.

The collected serum was stored at $-80^{\circ} \mathrm{C}$ at the Center for Advanced Medical and Pharmaceutical Research of the University of Medicine and Pharmacy Tîrgu Mures until serological determination was performed. We used to determine serum fascin level a quantitative sandwich ELISA kit from USBiological (Salem, MA, USA; Human fascin no.cat.024943, detection range $0.312-20 \mathrm{ng} / \mathrm{ml}$ ), according to the manufacturer's standard protocol.

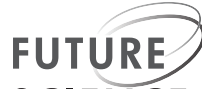

SCIENCE 


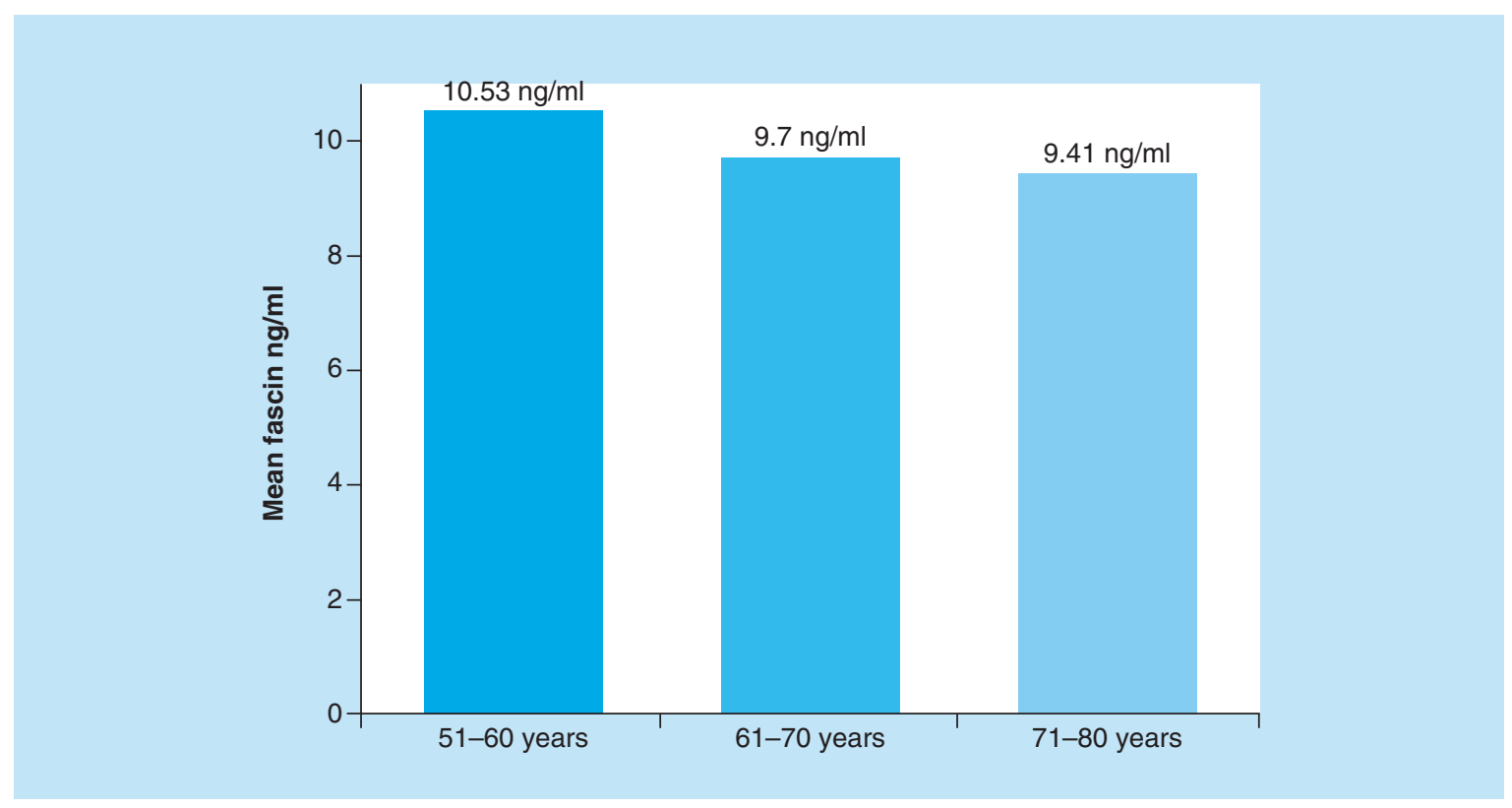

Figure 1. Fascin serum levels in subgroups.

Briefly, $100 \mu \mathrm{l}$ of serum, standards and blank were added to a precoated 96 -well microplate at $37^{\circ} \mathrm{C}$ for $1 \mathrm{~h}$. After discarding the reaction solution, a subsequent incubation was performed with appropriate detection of antibodies at $37^{\circ} \mathrm{C}$ for $1 \mathrm{~h}(100 \mu \mathrm{l})$. Following three washes and aspirations with washing solution, secondary antibodies $(100 \mu \mathrm{l})$ were added to each well followed by incubation at $37^{\circ} \mathrm{C}$ for $30 \mathrm{~min}$. After five additional aspirations and washes, a $90 \mu \mathrm{l}$ of 3,3,5,5-tetramethylbenzidine solution was added into each well and incubated at $37^{\circ} \mathrm{C}$ for $25 \mathrm{~min}$ under light-protected conditions. Finally, a $50 \mu \mathrm{l}$ of stop solution ( $2 \mathrm{M}$ sulfuric acid) was added to stop the reaction, and the absorbance was measured immediately at $450 \mathrm{~nm}$ using a microplate reader (DSX ${ }^{\mathrm{TM}}$ Automated ELISA System Dynex Technologies, VA, USA).

\section{Statistical analysis}

Statistical analysis was carried out using GraphPad InStat 3 software program. The Kolmogorov-Smirnov test was used to assess the normal distribution of continuous numerical variables. The results were presented as numbers and percentages for qualitative variables and as mean \pm standard deviation or median values for quantitative variables. Means were compared using Fisher's Exact test. A value of $\mathrm{p}<0.05$ was considered statistically significant.

\section{Results}

The included patients were divided into three subgroups: first group with age between 51 and 60 years old patients (11 patients), the second group included patients with age between 61 and 70 years (25 patients) and the third group contained patients with age between 71 and 80 years (ten patients).

Prostate-specific antigen (PSA) level was determined for each patient followed by prostate volume measurement and digital rectal examination. Due to clinical suspicion of prostate cancer (PCa) eight subjects underwent 12 core ultrasound guided biopsy. All eight patients had negative biopsies for PCa. In this subgroup mean serum fascin was $9.73 \mathrm{ng} / \mathrm{ml}$ (range: $7.35-13.65 \mathrm{ng} / \mathrm{ml}$ ) and mean PSA: $9.05 \mathrm{ng} / \mathrm{ml}$ (range: $3.61-15.27 \mathrm{ng} / \mathrm{ml}$ ).

The median age was 64 years (interquartile range [IQR]: 53-78). Mean fascin serum level was $9.84 \mathrm{ng} / \mathrm{ml}$ (range $3.96-17.63 \mathrm{ng} / \mathrm{ml}$ ) and the mean PSA level was $2.74 \mathrm{ng} / \mathrm{ml}$ (range: $0.14-15.27 \mathrm{ng} / \mathrm{ml}$ ). The mean prostate volume was $37.64 \mathrm{cc}$ (range: $10-120 \mathrm{cc}$ ).

The 51-60 years group had an mean fascin level of $10.53 \mathrm{ng} / \mathrm{ml}($ range: $3.96-17.63 \mathrm{ng} / \mathrm{ml})$, the $61-70$ group a mean of $9.7 \mathrm{ng} / \mathrm{ml}$ (range: $4.92-14.36 \mathrm{ng} / \mathrm{ml}$ ) and the 71-80 group had a mean of $9.41 \mathrm{ng} / \mathrm{ml}$ fascin serum level (range: $4.82-14.27 \mathrm{ng} / \mathrm{ml}$ ), with no statistical difference of fascin serum level between groups $(\mathrm{p}=0.65$, Figure 1$)$. 


\section{Discussion}

Fascin represents a highly studied protein in the current literature, due to its role in cancer progression and metastasis. The epithelial expression of fascin is clearly elevated in localized and hormone refractory PCa in comparison with healthy males, presenting benign prostate hyperplasia [6]. Fascin is an F-actin-bundling protein shown to stabilize filopodia and regulate adhesion dynamics in migrating cells [9,10], and its expression is correlated with poor prognosis and increased metastatic potential in a number of cancers [11].

Serum fascin determination was performed only on patients with small cell lung cancer [12], laryngeal carcinoma [13] and in patients with hepatocelular carcinoma (HCC) [14]. Serum level of fascin was associated with tumor aggressiveness in lung and laryngeal carcinomas, but still their results are presenting heterogeneous data regarding serum fascin in healthy individuals.

Our results are in concordance with Elewa et al. [14] findings about serum fascin in controls. They analyzed serum fascin using an ELISA kit from New East Biosciences in only 15 controls and the mean serum level of fascin was around $9.9 \mathrm{ng} / \mathrm{ml}$ (with 33.17 less than in HCC patients), value close to ours $9.84 \mathrm{ng} / \mathrm{ml}$ obtained after testing fascin in 46 males. Even more they found that in 50 patients with HCC, mean serum fascin was $14.8 \mathrm{ng} / \mathrm{ml}$; significantly higher than in controls or cirrhotic patients (20 patients).

Further analysis of fascin levels is needed in order to establish the correlation between elevated fascin serum levels and biopsy proven PCa or in associations with other tissue and serum markers [15,16]. Furthermore, the sensitivity and the specificity of the determination can be evaluated. Including other parameters of the patients could improve our results, such as free-PSA and testosterone levels.

In 2015, Loeb et al. published an article about Prostate Health Index proving the importance in a multivariable approach reducing prostate biopsies and avoiding overtreatment [17]. Fascin determination in association with prostate health index could play a significant role in the diagnosis of clinically significant PCa.

Limitations of this study include those inherit to a pilot study. Although a larger number of subjects might increase the statistical strength of the study, still we report the largest cohort of males in which serum fascin was determined and we confirmed that fascin is secreted in serum of healthy males (without malignancies). As fascin might play a role as serum biomarker in metastatic cancer and could be a target for therapy, it is important to have a reference level to report at when investigating serum levels of fascin in cancer patients.

\section{Conclusion}

Fascin is secreted in male's serum. From our data, serum level did not differ according to age in males and had a mean value of $9.84 \mathrm{ng} / \mathrm{ml}$.

\section{Future perspective}

Fascin was found to be secreted in serum of males according to our results. This might open further researches to identify if fascin could be a new biomarker for patients risk stratification or for predicting oncological outcomes in patients with cancer. As it is established that fascin plays a role in cell migration and metastasis, it is important to investigate fascin in serum of patients with neoplasia.

\section{Authors' contributions}

MD Vartolomei, O Martha and D Porav-Hodade had full access to all the data in the study and takes responsibility for the integrity of the data and the accuracy of the data analysis. MD Vartolomei prepared study concept and design. D Porav-Hodade, O Martha, D Balan, A Sin, S Tataru, A Hutanu, MD Vartolomei drafted the manuscript. MD Vartolomei performed critical revision of the manuscript for important intellectual content.

Financial \& competing interests disclosure

This paper was supported by an internal grant financed by University of Medicine and Pharmacy, Tîrgu Mureş, Romania. 'Fascin an eventual new biomarker in prostate cancer'. Contract number: 17800/22.12.2015. Samples storage and ELISA determination was performed at Center for Advanced Medical and Pharmaceutical Research, University of Medicine and Pharmacy, Tîrgu Mures, Romania. MD Vartolomei was supported by an EUSP scholarship awarded by the European Association of Urology. The authors have no other relevant affiliations or financial involvement with any organization or entity with a financial interest in or financial conflict with the subject matter or materials discussed in the manuscript apart from those disclosed.

No writing assistance was utilized in the production of this manuscript. 
Ethical conduct of research

The authors state that they have obtained appropriate institutional review board approval or have followed the principles outlined in the Declaration of Helsinki for all human or animal experimental investigations. In addition, for investigations involving human subjects, informed consent has been obtained from the participants involved.

Open access

This work is licensed under the Creative Commons Attribution 4.0 License. To view a copy of this license, visit http://creativecommons.org/licenses/by/4.0/

\section{Executive summary}

- Fascin is a $55 \mathrm{kDa}$ globular protein with important role in cell migration.

- The expression of fascin is greatly increased in many transformed cells, as well as in specialized normal cells including neuronal cells and antigen-presenting dendritic cells.

- The serum level of Fascin-1 is low or almost absent in the normal epithelia, but high levels of Fascin-1 were identified in various cancer types, with important role in tumor progression, invasion and metastasis.

- Fascin serum levels could represent an accessible biomarker in prostate cancer.

Study hypothesis

- Fascin serum levels could differ in various age groups.

- We aimed to determine if there is a correlation between prostate-specific antigen and fascin serum levels. Discussion

- Fascin is an F-actin bundling protein shown to stabilize filopodia and regulate adhesion dynamics in migrating cells, and its expression is correlated with poor prognosis and increased metastatic potential in a number of cancers.

- Serum fascin determination was performed only on patients with small cell lung cancer, laryngeal carcinoma and in patients with hepatocelular carcinoma.

Conclusion

- Fascin is indeed secreted in serum of healthy males with no statistical significance between age groups.

- This results could represent a stable reference point when measuring fascin serum levels in men.

\section{References}

Papers of special note have been highlighted as: $\bullet$ of interest; $\bullet \bullet$ of considerable interest

1 Hashimoto Y, Skacel M, Adams JC. Roles of fascin in human carcinoma motility and signaling: prospects for a novel biomarker? Int. J. Biochem. Cell Biol. 37(9), 1787-1804 (2005).

-. The role of fascin protein in human biology.

2 Kulasingam V, Diamandis EP. Fascin-1 is a novel biomarker of aggressiveness in some carcinomas. BMC Med. 11, 53 (2013).

- Aggressive cancers in association with fascin serum levels.

3 Machesky LM, Li A. Fascin: Invasive filopodia promoting metastasis. Commun. Integr. Biol. 3(3), 263-270 (2010).

$4 \mathrm{Bi} \mathrm{J}$, Chen X, Zhang Y et al. Fascin is a predictor for invasiveness and recurrence of urothelial carcinoma of bladder. Urol. Oncol. 30(5), 688-694 (2012).

- The role of fascin protein in human biology.

5 Zhao H, Yang F, Zhao W, Zhang C, Liu J. Fascin overexpression promotes cholangiocarcinoma RBE cell proliferation, migration, and invasion. Technol. Cancer Res. Treat. 15(2), 322-333 (2016).

- Fascin serum determination in other malignancies.

6 Darnel AD, Behmoaram E, Vollmer RT et al. Fascin regulates prostate cancer cell invasion and is associated with metastasis and biochemical failure in prostate cancer. Clin. Cancer Res. 15(4), 1376-1383 (2009).

- The role of fascin protein in human biology.

7 Park K-S, Lee HW, Park S-H, Park TI, Hwang J-H. The clinical significance of fascin expression in a newly diagnosed primary glioblastoma. J. Neurooncol. 129(3), 495-503 (2016).

8 Wang C-Q, Tang C-H, Chang H-T et al. Fascin-1 as a novel diagnostic marker of triple-negative breast cancer. Cancer Med. 5(8), 1983-1988 (2016).

9 Jayo A, Malboubi M, Antoku S et al. Fascin regulates nuclear movement and deformation in migrating cells. Dev. Cell 38(4), 371-383 (2016). 
10 Baumann K. Cell migration: fascin and 3D nuclear moves. Nat. Rev. Mol. Cell Biol. 17(10), 608-609 (2016).

11 Ma Y, Machesky LM. Fascin1 in carcinomas: its regulation and prognostic value. Int. J. Cancer 137(11), 2534-2544 (2015).

12 Teng Y, Xu S, Yue W et al. Serological investigation of the clinical significance of fascin in non-small-cell lung cancer. Lung Cancer Amst. Neth. 82(2), 346-352 (2013).

13 Lee L-Y, Chen Y-J, Lu Y-C et al. Fascin is a circulating tumor marker for head and neck cancer as determined by a proteomic analysis of interstitial fluid from the tumor microenvironment. Clin. Chem. Lab. Med. 53(10), 1631-1641 (2015).

14 Elewa MAF, Al-Gayyar MM, Schaalan MF, Abd El Galil KH, Ebrahim MA, El-Shishtawy MM. Hepatoprotective and anti-tumor effects of targeting MMP-9 in hepatocellular carcinoma and its relation to vascular invasion markers. Clin. Exp. Metastasis 32(5), 479-493 (2015).

15 Mathieu R, Lucca I, Vartolomei MD et al. Role of survivin expression in predicting biochemical recurrence after radical prostatectomy: a multi-institutional study. BJU Int. 119(2), 234-238 (2017).

16 Briganti A, Giannarini G, Klatte T, Catto JW, Shariat SF. The future of prostate cancer diagnosis: biomarkers, biopsy, both, or neither? Eur. Urol. Focus 1(2), 97-98 (2015).

17 Loeb S, Sanda MG, Broyles DL et al. The prostate health index selectively identifies clinically significant prostate cancer. J. Urol. 193(4), 1163-1169 (2015). 
